Article

\title{
Buffer-Mediated Effects of Clearcutting on In-Pool Amphibian Productivity: Can Aquatic Processes Compensate for Terrestrial Habitat Disturbance?
}

\author{
Jessica S. Veysey Powell * and Kimberly J. Babbitt \\ Department of Natural Resources and the Environment, University of New Hampshire, 56 College Road, \\ Durham, NH 03824, USA; kbabbitt@unh.edu \\ * Correspondence: jsveysey@gmail.com; Tel.: +1-603-659-2980
}

Academic Editor: Deanna H. Olson

Received: 10 October 2016; Accepted: 19 December 2016; Published: 24 December 2016

\begin{abstract}
Natural resource extraction and wildlife conservation are often perceived as incompatible. For wetland-dependent amphibians, forested buffers may mitigate timber-harvest impacts, but little empirical research has focused on buffers around lentic habitats. We conducted a landscape experiment to examine how spotted salamander and wood frog reproductive output (i.e., eggmass and metamorph production) respond to clearcutting mediated by buffers of different widths (i.e., uncut, $30 \mathrm{~m}$ buffer, $100 \mathrm{~m}$ buffer) at ephemeral pools in an industrial forest. We found complex interactions between buffer treatment and reproductive output, which were strongly mediated by hydroperiod. Overall, reproductive output was most sensitive at $30 \mathrm{~m}$-buffer pools and for salamanders, but responses diverged across productivity metrics even within these categories. Notably, for both cut treatments over time, while salamander eggmass abundance decreased, metamorph productivity (i.e., snout-vent length [SVL] and abundance) tended to increase. For example, average metamorph SVLs were predicted to lengthen between 0.2 and $0.4 \mathrm{~mm}$ per year post-cut. Additionally, typical relationships between reproductive output and hydroperiod (as indicated by the reference treatment) were disrupted for both species in both cut treatments. For example, long-hydroperiod pools produced more salamander metamorphs than short-hydroperiod pools in both the reference and $30 \mathrm{~m}$-buffer treatments, but the rate of increase was lower in the $30 \mathrm{~m}$-buffer treatment such that a long-hydroperiod pool in the reference treatment was predicted to produce, on average, 24 more metamorphs than a similar pool in the $30 \mathrm{~m}$-buffer treatment. From a conservation perspective, our results highlight the importance of evaluating both terrestrial and aquatic responses to terrestrial habitat disturbance, since responses may be reinforcing (i.e., exert similarly positive or negative effects, with the potential for amplification in the aquatic habitat) or decoupled (i.e., operate independently or be negatively correlated, with responses in the aquatic habitat potentially dampening or counteracting responses in the terrestrial habitat).
\end{abstract}

Keywords: Ambystoma maculatum; eggmass; ephemeral pool; hydroperiod; Lithobates sylvaticus; metamorph; reproductive output

\section{Introduction}

Pressure to manage forests for multiple uses is increasing globally as climate change progresses, and renewable energy demands, human populations, and per capita land consumption grow [1]. Natural resource extraction and wildlife conservation are two uses that are frequently pitted against each other during inter-user discussions over forest management plans [2-4]. Clearcuts are an effective timber harvest technique for diversifying the age structure of trees within forests and for creating habitat for wildlife species that specialize in young forest habitats, but there is evidence that clearcuts negatively impact most amphibian species (e.g., [5-7]). 
For wetland-dependent amphibians, forested buffers adjacent to wetlands hold promise as a simple technique for mitigating the impacts of clearcuts. Buffers effectively protect surface water quality and mitigate flooding [8-10]. In stream systems, where most manipulative buffer work has been conducted, riparian buffers have also been successfully used to mitigate the effects of clearcuts on multiple stream-dependent amphibian species (e.g., [11-13]). Considerably less research has focused on the wildlife value of buffers around lentic habitats [14,15]. While many stream-dependent amphibian species typically remain close to streams (i.e., within $100 \mathrm{~m}$ ), some wetland-dependent amphibians regularly range hundreds of meters into the surrounding landscape and thus may respond very differently to buffers [16-18].

To address the lack of empirical research on buffer utility for wetland-dependent amphibians, we conducted a landscape-scale experiment that examined how amphibian communities in ephemeral pools in an industrial forest respond to clearcutting mediated by buffers of different widths. Previously, we showed that even in the presence of buffers, clearcuts exerted negative effects on breeding-adult population composition and size structure, but that wider buffers mitigated some of these effects; specifically: 100-m-wide buffers were associated with larger adult recapture rates and body size than were 30 -m-wide buffers $[14,15]$. Here, we assess reproductive output (i.e., eggmass abundance and metamorph production) at these same pools, embedded within the same buffer treatments. We focus on two species that are aquatic as embryos and larvae, but leave their natal pools after metamorphosis, only to return during annual breeding events. The spotted salamander (Ambystoma maculatum) is long-lived and refrains from breeding during some years [19-21]. Conversely, the wood frog (Lithobates sylvaticus) typically lives less than half as long and may depend on annual reproductive output for population persistence [22-24]. These contrasting life-history strategies suggest that each species might respond uniquely to the different buffer treatments.

Though the relative importance of the aquatic phase may vary by species, it is important to determine whether effects on aquatic-phase productivity confirm or contrast with adult responses to buffer treatment for several reasons. First, for both species, regional populations persist through inter-pool dispersal and metamorphs are the primary dispersers [25-27]. Metamorph productivity thus constrains the number of dispersal propagules on the landscape. Second, metamorphs are a significant vector for transfer of energy and nutrients from the aquatic into the terrestrial system [28-30]. Finally, since eggmasses and larvae are confined to the pool basin and, unlike adults, cannot escape negative habitat conditions by moving to a different location, treatment impacts may manifest sooner or be more severe in these life stages.

Given their bi-phasic life histories, clearcutting could impact eggmass and metamorph production directly by changing environmental conditions in ephemeral pools and/or indirectly by altering the surrounding terrestrial habitat, causing adult amphibians to invest less of their energetic resources in reproduction and/or reducing breeding-population size through increased terrestrial-phase mortality and/or dispersal out of the population [31,32]. Ephemeral pools are complex systems, however, with dynamic food webs [28,33,34], competitive interactions [35-37], and high intra- and inter-annual variability $[23,28,38]$. A species' reproductive output depends not only on embryonic condition, but also on community composition [36,39,40]; conspecific density [23,41,42]; and environmental factors, like light, vegetative structure, hydroperiod, and temperature [43-45]. Negative larval density-dependence strongly shapes the number and condition of metamorphs emerging from pools $[23,46,47]$. Consequently, even if negative effects from the terrestrial environment carry-over into the aquatic phase via reduced eggmass quality (e.g., clutch size, egg lipid content), it is difficult to predict the ultimate effects on metamorph production. Negative terrestrial responses could be amplified in the aquatic phase or disrupted by complex in-pool interactions. Nevertheless, we made the following initial predictions for both species.

1. Eggmass abundance would increase with buffer width because eggmass number is positively correlated with adult abundance and wider buffers provide forested habitat for more adults. 
2. The number of metamorphs produced and metamorph snout-vent length would be negatively correlated with buffer width because these metamorphic traits are strongly shaped by negative density dependence in the larval stage. Thus, if eggmass abundance increased with buffer width (due to increased adult abundance), larval density should increase, and metamorph productivity decrease, with buffer width.

3. Any treatment effects on eggmass and metamorph abundance and metamorph length would diminish over time as clearcuts regenerated. However, wood frogs would respond faster to regeneration than spotted salamanders, since wood frogs breed every year, whereas individual salamanders often skip years between breeding. Further, wood frogs can generate many times more metamorphs than spotted salamanders, during productive years [48].

\section{Materials and Methods}

We used eleven natural ephemeral pools from a private, industrial forest in east-central Maine, USA for this study. We randomly assigned each pool to one of three treatments: reference (i.e., uncut; $N=3), 100 \mathrm{~m}$ buffer $(N=4)$, or $30 \mathrm{~m}$ buffer $(N=4)$. During winter 2003-2004, we used clearcutting to create experimental buffers such that post-cut, pools in the two buffer treatments had, respectively, a 100-m or 30-m-wide upland buffer encircling the pool and a 100-m-wide concentric clearcut around the buffer (Figure 1).

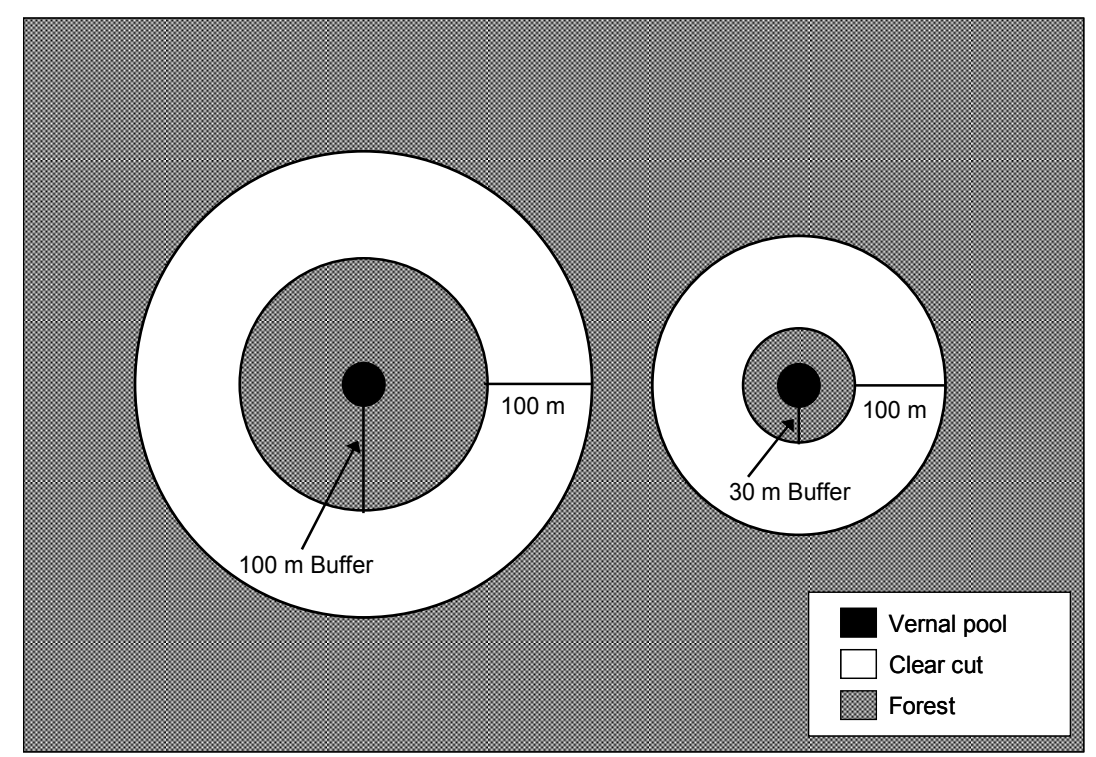

Figure 1. Experimental design implemented at 11 natural ephemeral pools in east-central Maine, USA. Undisturbed buffers of either $100 \mathrm{~m}$ (left; $n=4$ ) or $30 \mathrm{~m}$ (right; $n=4)$ were left adjacent to pools and $100 \mathrm{~m}$ wide clearcuts were created around the buffers. Forest beyond the clearcut was undisturbed. No cutting occurred at reference pools (not shown; $n=3$ ) [18].

From 2004 to 2009, we used a circular drift fence/pit fall trap array, installed within the forest/buffer and about $5 \mathrm{~m}$ upgradient from the high-water elevation of each pool, to capture, count, and sex all spotted salamanders and wood frogs emerging from the pools. We also measured the snout-vent/snout-urostyle (SVL) length of each emerging metamorph, except for brief periods in mid-July of 2004-2006 and 2008 when emerging metamorphs were excessively abundant at certain pools and we were unable to measure each individual. During these periods, we measured as many metamorphs as logistically possible.

We conducted annual eggmass counts for each species in each pool, starting in 2003 (i.e., pre-cut). Between 26 April and 20 May, we censused each pool for eggmasses on at least two occasions, with successive census dates for a given pool at least one week apart. Because eggmass integrity degrades 
relatively quickly, we were easily able to distinguish the old from the new eggmasses during the second census for each pool. For each species, we used the total number of novel eggmasses observed across the multiple sampling dates as the eggmass count for a given pool in a given year. We assume that eggmass detection approached $100 \%$ because the pools were relatively small and had clear water, allowing easy movement and high visibility throughout the pool during the censuses. Finally, we documented hydroperiod, or the number of days a pool held water between ice-out and the day the pool dried completely, for each pool in each year. For more details on the study site, experimental design, amphibian sampling, and hydroperiod determination, see Veysey Powell and Babbitt [14].

\subsection{Statistical Analyses}

To assess the relative impacts of forestry treatment and hydroperiod on spotted salamander and wood frog eggmass abundance and metamorph SVL, and on wood frog metamorph abundance, we developed linear mixed-effects regression models (LME) using the "lme" function in S-Plus 8.0 (Insightful Corporation, Seattle, WA, USA, 2007). Because salamander metamorph abundance was zero-inflated, we modeled this metric using a two-part process. During the first step, we used the "glme" function in the correlatedData library of S-Plus 8.0 to create a mixed-effects logistic regression model with a logit link that specified whether or not a given pool produced salamander metamorphs in a given year (hereafter: the Metamorph-Presence model). During the second step, we used LME to model metamorph abundance for those instances when abundance was greater than zero (hereafter: the Metamorph-Count model). To meet the assumptions of LME, we used $\ln (y+0.5)$ as the outcome variable in all of the LME-based abundance analyses.

We treated year and pool ID as crossed random effects [49], except in the following cases. (1) For the wood frog SVL model, we treated pool ID and month-nested-within-year as crossed random effects. (2) If a model did not converge with crossed effects, we simplified the model to include either a random intercept for year or for pool, whichever provided a better model fit, as determined by likelihood ratio tests (LRTs). For this reason, we only used pool random intercepts in the salamander SVL and Metamorph-Presence models. We also modeled the variance-covariance structure for each regression to account for heterogeneous variance across groups and correlation among individuals from the same pool (Table S1). We used LRTs to optimize the variance-covariance structure of each model.

We included the following predictor variables in all models: buffer treatment, pool hydroperiod, an interaction between treatment and pool hydroperiod, and a pair of numeric dummy variables representing an interaction between treatment and study year. We used the first dummy variable (cut.year) to distinguish whether a pool was subjected to clearcutting or not. We used the second dummy variable ( $30 \mathrm{~m}$.year) to indicate marginal impacts to the $30 \mathrm{~m}$ treatment pools. To represent hydroperiod in the eggmass models, we used both mean pool hydroperiod (i.e., the mean hydroperiod for each pool across the six study years) and the standard deviation of pool hydroperiod (as calculated for each pool across the six study years) as predictors, and included mean pool hydroperiod in the interaction. In the metamorph models, we used the current-year hydroperiod (i.e., the hydroperiod documented in a given [individual] study year) as the hydroperiod metric.

Additionally, we included the total number of metamorphs produced in a given pool in a given year as a predictor in the metamorph SVL models, and both breeding-female abundance and eggmass abundance as predictors in the metamorph-abundance models. We also wanted to include breeding-female abundance as a predictor in the eggmass-abundance models. However, we had eggmass data for 2003-2009 (the 2003 data were from the year preceding the clearcut), but only had female abundance data for 2004-2009. Thus, we present two alternative models per species for eggmass abundance. The first includes the pre-cut eggmass data from 2003 (in addition to the eggmass data from 2004 to 2009), but not female abundance (hereafter: the Pre-cut Eggmass model). The second includes female abundance and the eggmass data from 2004 to 2009, but not the 2003 eggmass data (hereafter: the Female Eggmass model). 
We used analyses of variance (i.e., ANOVAs_ to determine the overall significance of each fixed effect and $t$ tests to assess the significance of the different treatment levels $(\alpha=0.05)$. We used treatment contrasts to compare the reference treatment to each respective cut treatment. Based on the results of these initial inter-treatment comparisons, we subsequently performed a post-hoc comparison between the $100 \mathrm{~m}$ and $30 \mathrm{~m}$ treatments for the salamander metamorph SVL model. Based on an a priori decision, we removed the hydroperiod interaction from a model if the interaction was not significant and refit the model for the remaining fixed effects. Ultimately, we dropped the hydroperiod interaction from the salamander Metamorph-Presence model, and the wood frog metamorph and eggmass abundance models. In their final forms, all models satisfied their respective regression assumptions.

\subsection{Compliance with Ethical Standards}

We conducted all of the research in accordance with the rules of the Institutional Animal Care and Use Committee at the University of New Hampshire (IACUC-UNH). IACUC-UNH approved our research protocol, as detailed in permits: 020601 and 050604.

\section{Results}

Across the study period and the 11 ephemeral pools, we censused 3030 and 3877 eggmasses and counted 2645 and 26819 metamorphs for spotted salamanders and wood frogs, respectively. We provide descriptive statistics for the relevant demographic and hydroperiod data in Table 1. Two pools (one reference, one $100 \mathrm{~m}$ ) failed to produce salamander metamorphs during the study, though salamander eggmasses were deposited in the reference pool every year and in the $100 \mathrm{~m}$ pool every year, except 2006. Notably, these two pools had the shortest mean hydroperiods (i.e., 45 and 66 days, respectively) of all pools. This reference pool also only produced 12 wood frog metamorphs during the study, though frog eggmasses were deposited in all years, except 2005 and 2006. Over all 65 year X pool cases (where "case" refers to the unique data generated for each species at a single pool in a single year), no metamorphs were produced in $37 \%$ of the frog and $12 \%$ of the salamander cases, and fewer than 10 metamorphs were produced in $17 \%$ of the frog and $31 \%$ of the salamander cases. All results presented in the rest of this section were statistically significant, unless otherwise indicated. (We use the phrase "tended to" to denote marginally significant results; i.e., $0.05 \leq p \leq 0.09$ ).

Table 1. Mean and variability for amphibian abundance and pool hydroperiod across the 11 study pools and 6 study years ${ }^{a}$.

\begin{tabular}{|c|c|c|c|c|}
\hline & Mean $\pm S E$ & Range & & \\
\hline \multicolumn{5}{|l|}{ hydroperiod (days) } \\
\hline current-year & $126 \pm 7$ & $0-211$ & & \\
\hline mean & $126 \pm 6$ & $45-197$ & & \\
\hline \multirow[t]{3}{*}{ standard deviation } & $32 \pm 2$ & $6-49$ & & \\
\hline & \multicolumn{2}{|c|}{ Spotted Salamander } & \multicolumn{2}{|c|}{ Wood Frog } \\
\hline & Mean \pm SE & Range & Mean $\pm \mathrm{SE}$ & Range \\
\hline \multicolumn{5}{|l|}{ \# Eggmasses } \\
\hline Reference & $35 \pm 5$ & 0-90 & $56 \pm 10$ & $23-235$ \\
\hline $100 \mathrm{~m}$ & $52 \pm 11$ & $0-200$ & $38 \pm 6$ & $0-105$ \\
\hline $30 \mathrm{~m}$ & $31 \pm 4$ & $4-79$ & $58 \pm 11$ & $2-235$ \\
\hline \multicolumn{5}{|l|}{ \# Metamorphs } \\
\hline Reference & $28 \pm 11$ & $0-137$ & $587 \pm 331$ & $0-5905$ \\
\hline $100 \mathrm{~m}$ & $60 \pm 24$ & $0-462$ & $151 \pm 73$ & $0-1713$ \\
\hline $30 \mathrm{~m}$ & $30 \pm 10$ & 0-195 & $558 \pm 331$ & $0-7691$ \\
\hline \multicolumn{5}{|l|}{$\mathrm{SVL} / \mathrm{SUL}^{\mathrm{b}}(\mathrm{mm})$} \\
\hline Reference & $26.3 \pm 0.14$ & $20-42$ & $15.6 \pm 0.03$ & $8-28$ \\
\hline $100 \mathrm{~m}$ & $29.3 \pm 0.07$ & $19-43$ & $17.3 \pm 0.04$ & $10-32$ \\
\hline $30 \mathrm{~m}$ & $27.6 \pm 0.14$ & $18-45$ & $17.8 \pm 0.02$ & $10-33$ \\
\hline
\end{tabular}

a Eggmass data include one year of pre-cut data and six years of post-cut data; all other metrics are for six years of post-cut data; ${ }^{b}$ Snout-vent length or snout-urostyle length, for salamander and wood frogs, respectively. 


\subsection{Spotted Salamanders}

Salamander eggmass abundance declined over time in the cut treatments, as demonstrated by the significance of the "cut.year" parameter in the Pre-cut Eggmass model (Table S2; Figure 2). Though the mean decline rate for eggmass abundance was predicted to be about $9 \%$ per year, the most dramatic decline happened during the first year post-cut and in the $100 \mathrm{~m}$ treatment, a result derived by comparing results for "cut.year" across the two salamander eggmass models.

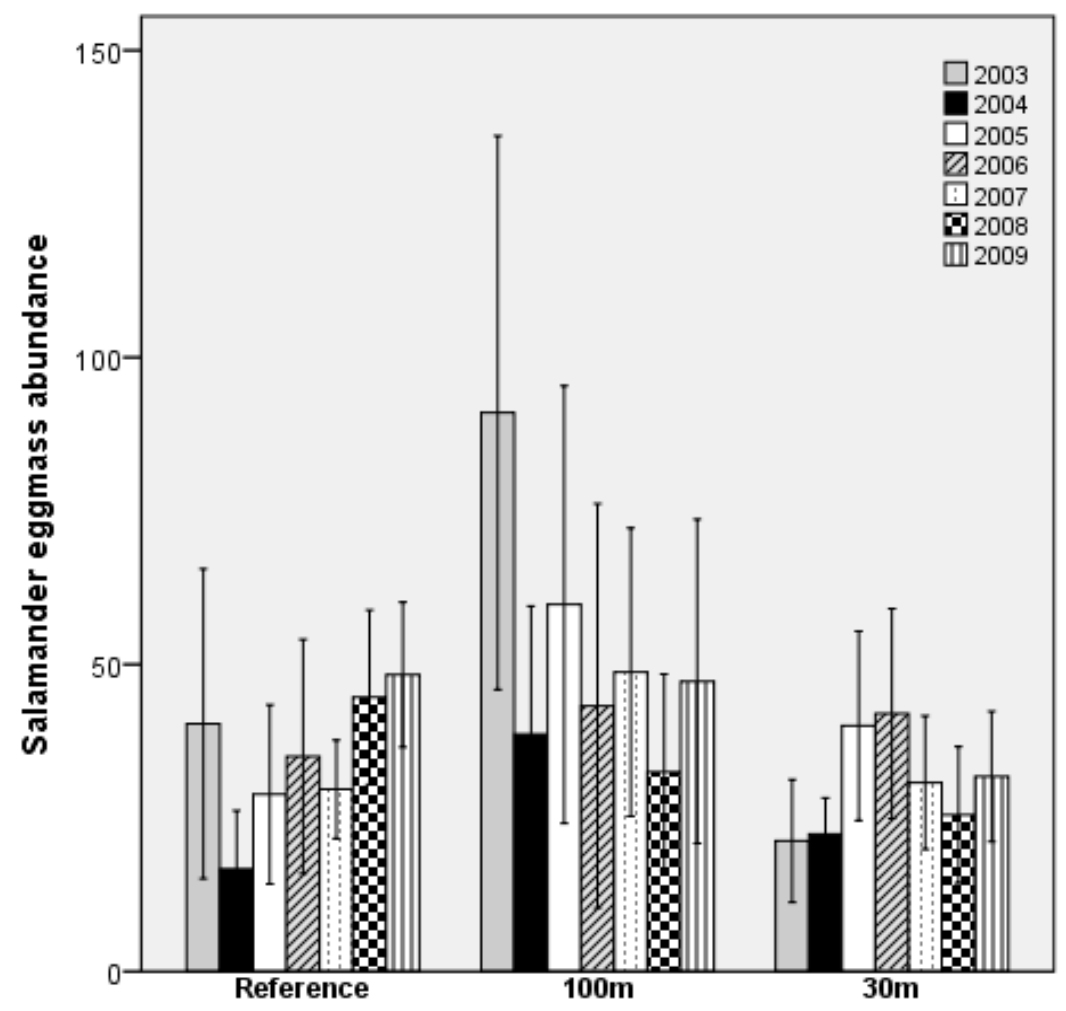

Figure 2. Mean ( $\pm 1 \mathrm{SE})$ annual abundance of spotted salamander eggmasses deposited in 11 natural ephemeral pools across 3 experimental forestry treatments in east-central Maine, USA. Treatments were: reference (uncut), $100 \mathrm{~m}$ undisturbed buffer, and $30 \mathrm{~m}$ undisturbed buffer. Eggmass data from 2003 was collected prior to the experimental cut; eggmass data from 2004 through 2009 were collected post-cut.

As expected, the Female Eggmass model showed that the number of eggmasses deposited tended to increase with the number of breeding females. Otherwise, the two eggmass-abundance models were consistent: they both showed that eggmass abundance in $100 \mathrm{~m}$ pools was partly a function of mean-pool hydroperiod and that the standard deviation of mean-pool hydroperiod was negatively associated with eggmass abundance across all treatments. Specifically, while eggmass abundance in the reference treatment was not significantly related to mean hydroperiod, abundance in the $100 \mathrm{~m}$ treatment increased by about $2 \%$ for each additional day of mean hydroperiod and tended to be lower at short-hydroperiod $100 \mathrm{~m}$ (versus reference) pools (Figure 3). Conversely, for each additional day that hydroperiod varied inter-annually, eggmass abundance decreased by just over $3 \%$.

Salamander metamorph abundance varied between pools and inter-annually. For instance, across all pools, we captured 1027 metamorphs in 2006, but only 44 in 2007; two pools (one reference and one 100-m buffer) did not produce metamorphs during the study. The Metamorph-Presence model, used to analyze whether or not individual pools produced salamander metamorphs in a given year, correctly classified $92 \%$ of cases. In both cut treatments, pools tended to be more likely to produce metamorphs as the cuts regenerated, such that for every additional year post-cut, the odds of a pool producing metamorphs increased by a factor of 3.2. Across all treatments, as expected, the pools were 
more likely to produce metamorphs when they held water for an extended period during the growing season. Specifically, for every additional day the pool held water in a given year, the odds of the pool producing any metamorphs increased by $7.4 \%$.

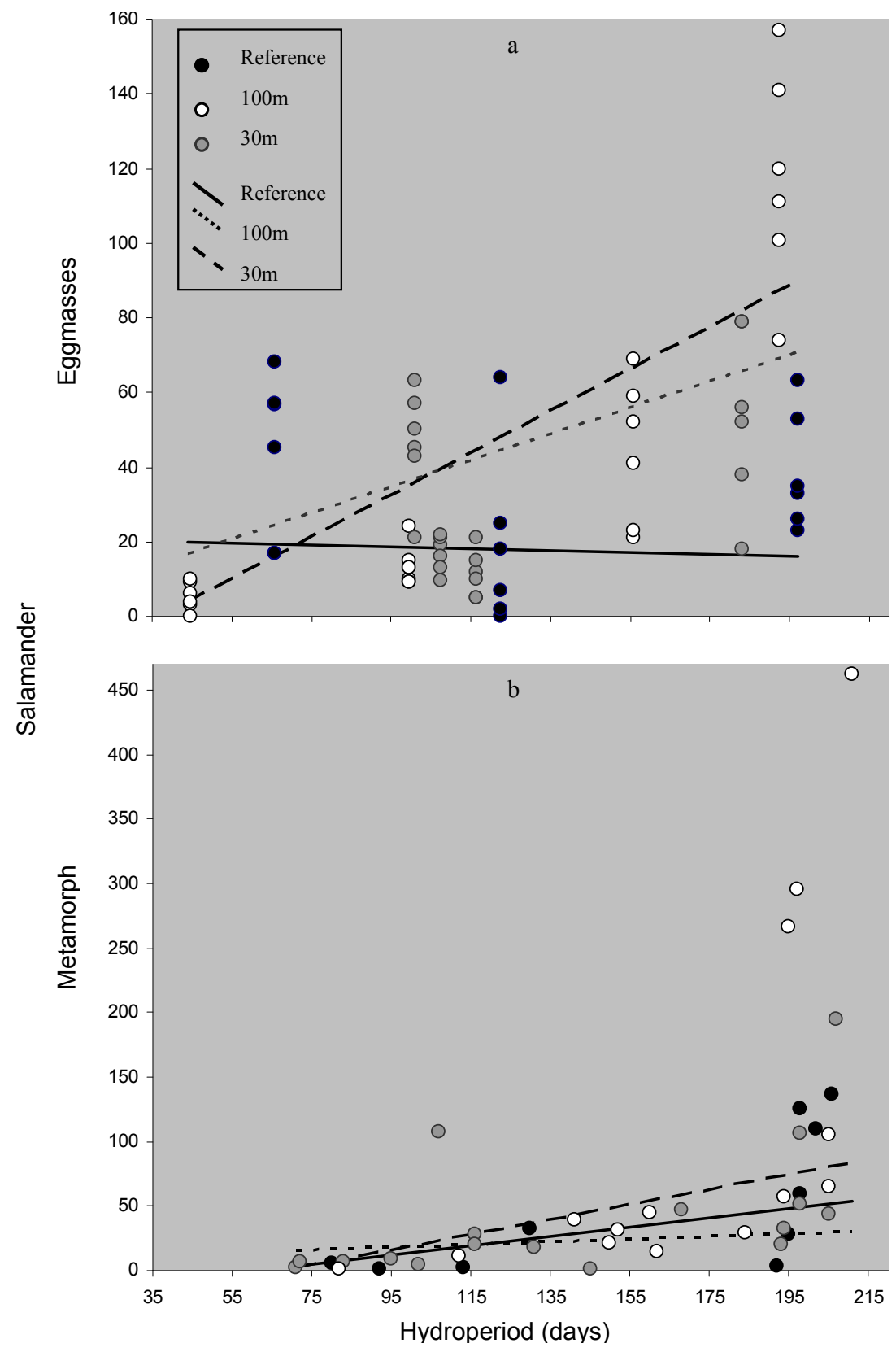

Figure 3. Spotted salamander abundance by hydroperiod (days) across 3 experimental forestry treatments at 11 natural ephemeral pools in east-central Maine, USA. Treatments were: reference (uncut), $100 \mathrm{~m}$ undisturbed buffer, and $30 \mathrm{~m}$ undisturbed buffer. (a) Eggmass abundance by mean-pool hydroperiod; (b) metamorph abundance, in pools that produced metamorphs, by current-year hydroperiod. Lines represent predicted values based on the fixed-effects regression coefficients.

Among the pools that produced metamorphs in a given year, the number of metamorphs that emerged depended, in the $30 \mathrm{~m}$ treatment, on both current-year hydroperiod and time since cut; and in all treatments, on eggmass abundance. On average, while metamorph abundance was predicted to increase by about $1.9 \%$ for every additional day of hydroperiod in the reference treatment, the production rate was significantly lower in the $30 \mathrm{~m}$ treatment, where metamorph abundance 
was predicted to increase by only about $0.44 \%$ per additional day that the pool held water (Figure 3 ). However, $30 \mathrm{~m}$ treatment pools with short hydroperiods tended to produce more metamorphs than short-hydroperiod reference pools. For example, and on average, we predicted that short-hydroperiod (e.g., 71 days) pools in the $30 \mathrm{~m}$ versus reference treatment would produce 16 versus 4 metamorphs, while long hydroperiod pools (e.g., 211 days) would produce 30 versus 54 metamorphs in the $30 \mathrm{~m}$ versus reference treatment. Additionally, metamorph abundance in the $30 \mathrm{~m}$ treatment tended to increase by about $0.45 \%$ for every year post-cut (i.e., on average, one additional metamorph was predicted at each $30 \mathrm{~m}$ pool over the entire study). Across all treatments, the number of metamorphs produced increased by about $1.3 \%$ for every additional eggmass deposited in the pool. For example, and on average, we predicted that a reference pool with 10 eggmasses would produce 8 metamorphs, while a similar pool with 100 eggmasses would produce 42 metamorphs. Finally, metamorph abundance was unrelated to breeding-female abundance.

Salamander metamorph SVL increased in the cut treatments over time, such that for every additional year post-cut, metamorphs were predicted to be $0.24 \mathrm{~mm}$ longer, on average (Figure 4 ). Conversely, the more metamorphs produced by a pool in a given year, the shorter each individual metamorph: for every additional metamorph emerging from the pool, the average metamorph length was predicted to decrease by $0.01 \mathrm{~mm}$. In a single year in a reference pool, for instance, and on average, we predicted that a typical metamorph would have a SVL of $24.5 \mathrm{~mm}$ if 100 additional metamorphs were produced in the pool, but a SVL of $23.5 \mathrm{~mm}$ if 200 additional metamorphs were produced. Finally, while metamorph SVL in the reference treatment was unrelated to current-year hydroperiod, metamorph SVL in both cut treatments tended to increase with hydroperiod, but at a faster rate (i.e., by about $0.048 \mathrm{~mm}$ more per day) in the $100 \mathrm{~m}$ versus $30 \mathrm{~m}$ treatment. For example, and on average, we predicted that the SVL of a typical metamorph would increase from $24.8 \mathrm{~mm}$ to $28.8 \mathrm{~mm}$ in short (e.g., 71 days) versus long (e.g., 211 days) hydroperiod pools in the $30 \mathrm{~m}$ treatment, but would increase from $21.7 \mathrm{~mm}$ to $32.4 \mathrm{~mm}$ as hydroperiod extended by the same amount in the $100 \mathrm{~m}$ treatment.

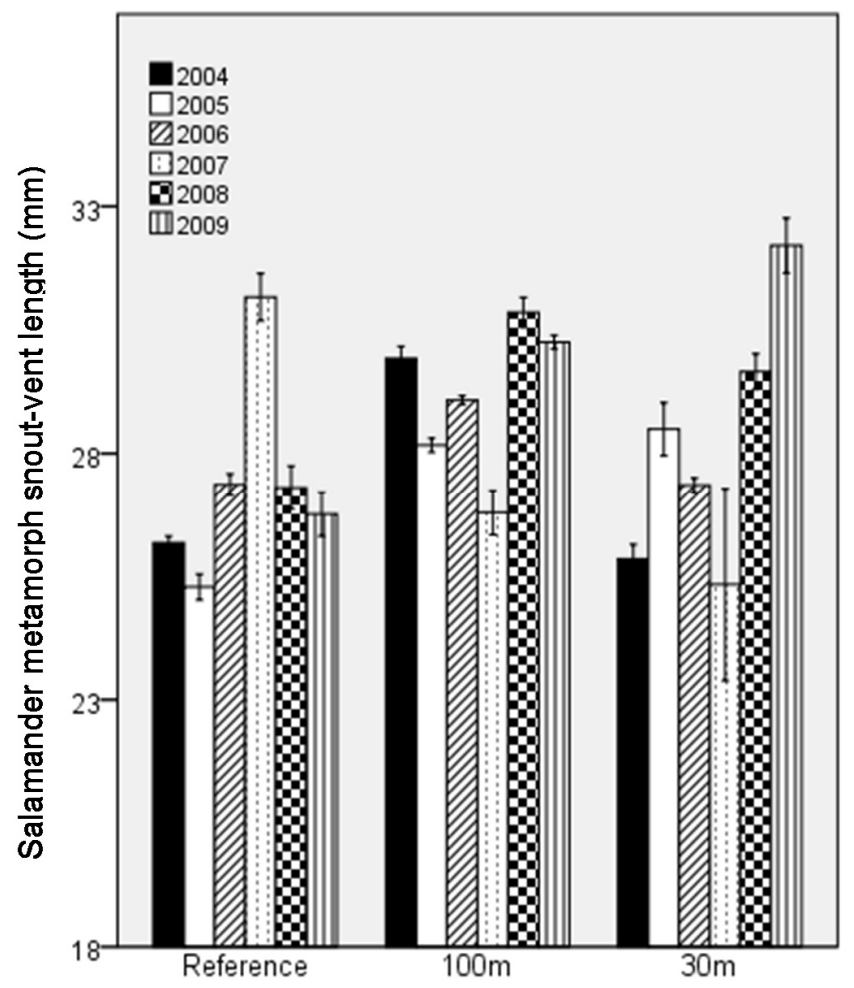

Figure 4. Mean ( $\pm 1 \mathrm{SE})$ spotted salamander metamorph snout-vent length, across 3 experimental forestry treatments and 6 study years at 11 natural ephemeral pools in east-central Maine, USA. Treatments were: reference (uncut), $100 \mathrm{~m}$ undisturbed buffer, and $30 \mathrm{~m}$ undisturbed buffer. 


\subsection{Wood Frogs}

Both eggmass models were consistent in that they showed no relationship between wood frog eggmass abundance and buffer treatment. According to the Female Eggmass model, the number of deposited eggmasses increased with the number of breeding females (by about $2 \%$ for each additional female), but decreased as the hydroperiod became more variable (by about $2 \%$ per additional day of variability). The Pre-cut Eggmass model, however, did not identify any significant relationships between the tested predictors and wood frog eggmass abundance.

Inter-pool and inter-annual wood frog metamorph production were highly variable. For example, during the five years that we collected metamorph data at one $30 \mathrm{~m}$ pool, the numbers of metamorphs produced were: 9, 51, 7691, 6, and 0 . We observed a similar boom-and-bust pattern at one of the reference pools. Though abundance in the remaining pools never spiked higher than 1700 metamorphs, these pools nevertheless also had quite variable production.

In the $30 \mathrm{~m}$ treatment, wood frog metamorph production increased over time. On average, for every additional study year, about $71 \%$ more wood frog metamorphs were predicted from $30 \mathrm{~m}$ pools. It is important to stress, however, that this is the average pattern identified via the deployed linear modeling technique; this technique directly accounted for pool and year-specific heterogeneity in metamorph production, but individual pools did deviate from this average pattern in particular years. Finally, and in all treatments, wood frog metamorph production increased as current-year hydroperiod increased (by about $3.1 \%$ for every additional day that a pool held water).

Wood frog metamorph SVL varied with most of the tested predictors. Mean metamorph SVL increased over time in both cut treatments, but at a faster rate in the $100 \mathrm{~m}$ versus $30 \mathrm{~m}$ treatment (by about $0.4 \mathrm{~mm}$ and $0.2 \mathrm{~mm}$ per year, respectively; Figure 5). The relationship between frog metamorph SVL and treatment also varied with current-year hydroperiod. Whereas at reference pools, mean SVL increased by $0.01 \mathrm{~mm}$ per additional day of hydroperiod, mean SVL decreased with hydroperiod in both cut treatments. For every additional day a pool held water, the average metamorph was $0.024 \mathrm{~mm}$ and $0.003 \mathrm{~mm}$ shorter in the $30 \mathrm{~m}$ and $100 \mathrm{~m}$ treatments, respectively. Further, metamorphs at short-hydroperiod pools were significantly longer in the $30 \mathrm{~m}$ versus reference treatment. Finally, across all treatments, the more metamorphs produced by a pool in a given year, the shorter the average metamorph.

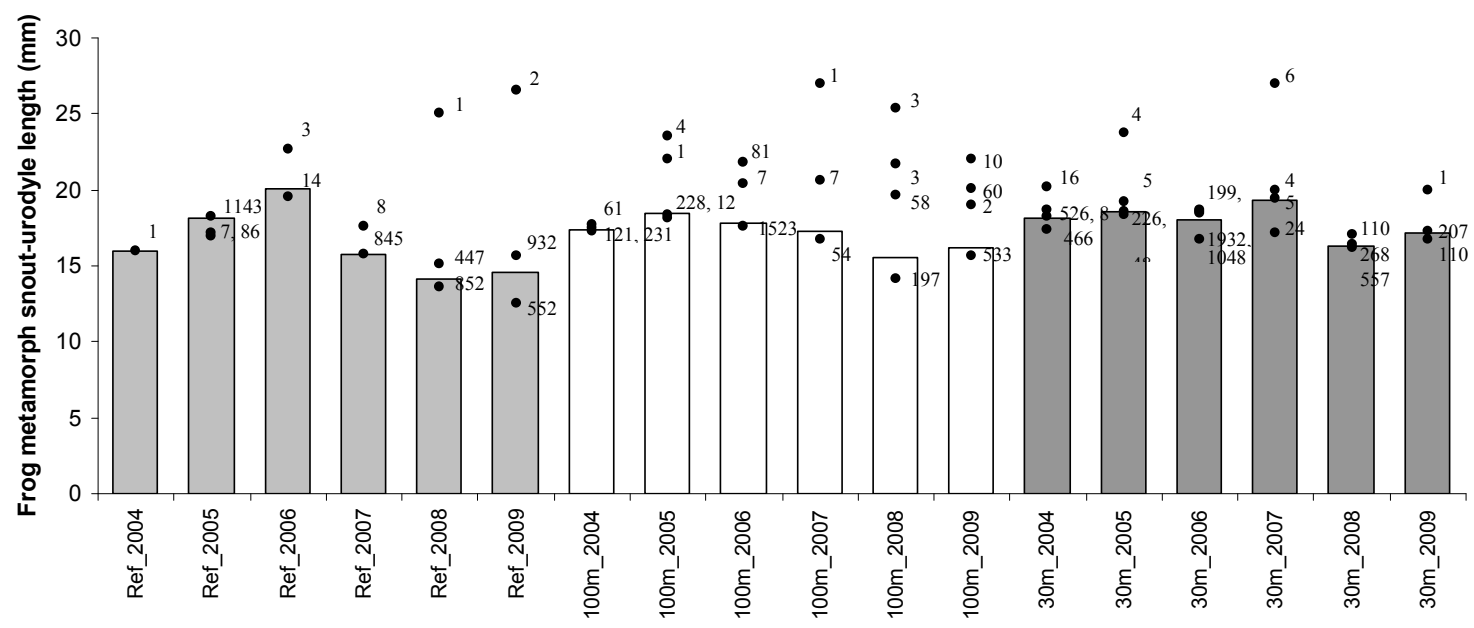

Figure 5. Mean wood frog metamorph snout-urostyle length by forestry treatment and study year. Bars represent the means across all individuals in a treatment in a given year. Points represent mean values for individual pools within each treatment in a given year, with the sample size for each pool provided by the number to the right of each point. These data are for populations at 11 natural ephemeral pools in east-central Maine, USA. Treatments were: reference (uncut), $100 \mathrm{~m}$ undisturbed buffer, and $30 \mathrm{~m}$ undisturbed buffer. 


\section{Discussion}

Sub-adult amphibians can serve as indicators of aquatic environmental conditions, connect terrestrial and aquatic energy cycles, constitute the pool of dispersal propagules, and presage future population size. It is thus important to understand how buffer width interacts with forest harvesting to influence sub-adult amphibian productivity. Contrary to our predictions, we observed neither consistently positive relationships between buffer width and eggmass abundance nor consistently negative relationships between buffer width and metamorph productivity. Nor did we find that treatment effects neatly diminished over time. Instead, our results reveal complex interactions between buffer treatment and productivity, which were strongly mediated by hydroperiod and, potentially, other environmental conditions. Overall, productivity was most sensitive at $30 \mathrm{~m}$ pools and for spotted salamanders, but we found divergent responses across productivity metrics even within these categories. In particular, for both cut treatments over time, while salamander eggmass abundance decreased, metamorph productivity tended to increase. As in many amphibian systems, our data were highly variable and potentially stochastic. We acknowledge the difficulty in modeling such systems and recognize that our sample size (i.e., 11 pools) and limited study period (i.e., six years) may also have constrained our ability to model treatment effects on amphibian reproductive output. Despite these potential limitations, we note that mixed-effects regression is a powerful statistical technique that specifically allowed us to model heterogeneity across individual pools and years. Further, we emphasize that our models describe average conditions. Thus, while the raw data are variable across individual pools and years, we use the models to understand mean responses to experimental treatments. That we were able to discover robust, significant mean trends within highly variable data actually indicates the strength of those trends. In the following discussion, we explore the mechanisms that potentially explain these mean, modeled results.

\subsection{Eggmass Abundance}

Eggmass abundance is a useful productivity measure for two principle reasons. Foremost, it directly reflects the terrestrial conditions experienced by breeding adults and is a pathway for those conditions to influence the aquatic community. In terrestrial life-stages, both species exhibit plastic resource allocation between growth, reproduction, storage, and maintenance [19,50,51]. In response to stressful terrestrial conditions, like clearcuts, individuals may prioritize allocation to maintenance and growth, at the expense of reproduction, leading to delayed maturity or, for salamanders, an extended inter-breeding interval $[15,52,53]$. In turn, breeding-population and eggmass abundance (which are typically tightly and positively correlated; [54-56]) can decline. Second, eggmass abundance provides a rough approximation of the number of embryos deposited in a pool and thus signifies constraints on maximum metamorph production.

Buffer treatment was not a significant predictor of wood frog eggmass abundance, suggesting that the terrestrial impacts of clearcutting on adult frogs were not severe enough to be perpetuated in the aquatic environment, at least not in the form of fewer deposited eggmasses. In Veysey Powell and Babbitt [14], we showed that fewer mature wood frogs were recaptured in the $30 \mathrm{~m}$ treatment (compared to the $100 \mathrm{~m}$ treatment), but that this was supplemented by immigration, which buoyed the breeding population. The eggmass results imply that adult immigration offset any potential decline in eggmass productivity otherwise associated with the loss of mature, resident breeders.

By contrast, buffer treatment was a strong predictor of spotted salamander eggmass abundance. Eggmass abundance decreased in both cut-treatments over time, with this average trend driven primarily by a marked drop in the $100 \mathrm{~m}$ treatment immediately post-cut. Decreased eggmass abundance was likely a direct consequence of declining breeding-female abundance in the cut treatments, which was more severe in the $100 \mathrm{~m}$ treatment-this may be explained by a combination of reduced philopatry and increased mortality and temporary emigration-and is explored in Veysey Powell and Babbitt [14]. In the $100 \mathrm{~m}$ treatment, recaptured-breeding-female body condition also 
declined over time [15], suggesting that $100 \mathrm{~m}$ treatment females may have restricted reproductive investment by limiting per capita eggmass production.

The relationship between hydroperiod and salamander eggmass abundance was also altered in the $100 \mathrm{~m}$ treatment. Whereas hydroperiod was not a significant predictor in the reference treatment, in the $100 \mathrm{~m}$ treatment, eggmass abundance was positively correlated with mean-pool hydroperiod and, among short-hydroperiod pools, there tended to be fewer eggmasses. We observed a similar pattern for multiple metrics across the broader experiment, including for salamanders: metamorph SVL and breeding-adult abundance; and for breeding, female frogs: SVL of recaptured individuals and biomass of new-captured individuals [14]. Such repetition suggests impaired terrestrial habitat quality in the $100 \mathrm{~m}$ treatment that triggered a tight link between hydroperiod and fitness.

Hydroperiod typically exerts strong controls on salamander development during aquatic life stages and subsequently on metamorph production, with long-hydroperiod pools generally producing greater numbers of more robust metamorphs $[41,57,58]$. The lack of a significant relationship between eggmass abundance and mean-pool hydroperiod in the reference treatment, however, suggests that in undisturbed conditions, the terrestrial environment provided sufficient resources to support reproductive maturation, despite disparities in metamorph starting point, and/or facilitated sufficient immigration to offset such disparities. Comparatively, terrestrial conditions in the $100 \mathrm{~m}$ treatment may not have been conducive to compensatory growth of metamorphs and juveniles originating from short-hydroperiod pools, leading to reduced abundance of breeding adults and, subsequently, eggmasses. Further research is needed to understand whether hydroperiod effects on metamorph productivity influence subsequent adult resource allocation and eggmass production. Addressing the potential for such carry-over effects is beyond the scope of the present study. Finally, we cannot satisfactorily explain why we did not find a similarly altered hydroperiod relationship in the $30 \mathrm{~m}$ treatment. Since eggmass abundance largely mirrors breeding-adult abundance, however, we refer to Veysey Powell and Babbitt [14], for hypotheses that could explain the hydroperiod-abundance patterns for both breeding-adults and eggmasses.

As one of two aquatic life-stages, eggmasses are an essential link in understanding how terrestrial forestry treatments could influence population size. Our results indicate that the negative effects of cutting on terrestrial adults were perpetuated in the aquatic environment in salamander, but not frog, eggmass abundance. For salamanders, this could limit metamorph productivity and population size. Given the complexity of in-pool interactions and variability in embryonic maternal investment, however, other outcomes are possible, as explored in the next section. Ultimately, understanding how eggmass abundance responds to buffer treatment may be most valuable as confirmation of adult-abundance patterns.

\subsection{Metamorph Productivity}

Metamorphs represent population potential: they are the newest generation of amphibians and their abundance and condition can strongly influence (meta) population dynamics $[25,59,60]$. They also embody a significant transfer of energy and nutrients from wetland to upland systems [28-30]. These roles are especially pronounced for wood frog metamorphs, which are produced by the thousands in boom years, and because wood frogs, having a relatively short life-span, depend on recruitment for persistence [23,61,62]. While metamorph productivity is a function of eggmass quantity and egg condition $[23,63,64]$, it is also influenced by in-pool conditions, like intra- and inter-specific competition, temperature, hydroperiod, predation, and refuge and food availability $[43,63,65]$. Consequently, buffer treatment can influence metamorph productivity via numerous pathways. We expected metamorph abundance and size to decrease with increasing buffer width, but our results were more complex. For both species and cut treatments, some results showed increased metamorph productivity over time, while others indicated altered hydroperiod dynamics. 


\subsubsection{Productivity over Time}

Over time, wood frog metamorph abundance increased in the $30 \mathrm{~m}$ treatment, while metamorph SVL increased in both cut treatments (SVL increased more slowly in the $30 \mathrm{~m}$ versus $100 \mathrm{~m}$ treatment). For spotted salamanders, metamorph SVL increased with time in both cut treatments. Our salamander results also indicated marginally significant trends of increased metamorph-production probability in both cut treatments and greater metamorph abundance in the $30 \mathrm{~m}$ treatment, over time. In general, these patterns did not represent a recovery following post-cut reductions in abundance or SVL, but rather a genuine increase beyond metamorph productivity observed at the reference pools. While logistics inhibited complete examination of potential explanatory mechanisms, we used adult demographic data from the larger experiment to isolate the most likely mechanisms.

Among the adult data, the only relevant metrics that increased over time were: (a) SVL and mass of new-captured female wood frogs in both cut treatments; and in the $30 \mathrm{~m}$ treatment; (b) mass and body condition of recaptured female spotted salamanders; (c) mass of recaptured male salamanders; and (d) SVL, mass, and body condition of new-captured male salamanders [14,15]. Larger females could contribute to increased metamorph abundance and SVL by producing more eggs per eggmass and/or eggs with higher nutrient content [66-68]. Similarly, larger males could enhance metamorph production through increased egg-fertilization rates $[69,70]$. However, these adult metrics increased only after a post-cut decline and were predicted to recover to reference levels between four and 11 years post-cut. Thus, increased adult size and condition may partially, but not completely, explain metamorph productivity patterns.

For cut-treatment salamanders, declining eggmass abundance could help explain increasing metamorph SVL. For all treatments, the SVL model indicated negative density dependence among larval salamanders, whereas the Metamorph-Count model showed that eggmass and metamorph abundance declined in tandem. Thus, in the cut treatments, the decline in eggmass abundance could lead to fewer metamorphs, a release from intra-specific competition, enhanced conditions for metamorph growth, and longer metamorphs. We also attribute inter-treatment differences in the rate of increase for wood frog SVLs over time to variation in density dependence. Though negative density dependence was indicated for all treatments, only in the $30 \mathrm{~m}$ treatment did metamorph abundance increase with time. Thus, intra-specific competition was likely greater, and metamorph SVL more constrained, over time in the $30 \mathrm{~m}$ versus $100 \mathrm{~m}$ treatment. Given the relatively large mean annual predicted increase in wood frog metamorph abundance at $30 \mathrm{~m}$ treatment pools (i.e., $71 \%$ more metamorphs per year), it is surprising that competition did not, apparently, limit SVLs even more severely in the $30 \mathrm{~m}$ treatment. This may be attributed to the fact that predicted metamorph abundance at the start of the study was low (e.g., $<25$ metamorphs) for short-to-medium hydroperiod (e.g., 40-130 days) pools; thus, even an annual increase in abundance of $71 \%$ would not generate great numbers of competing larvae and metamorphs. Only at pools with longer hydroperiods did we predict large numbers of metamorphs (e.g., >200) throughout the study. Overall, competitive effects on SVL in long-hydroperiod pools may have been offset by a lack of competition in the short-medium hydroperiod pools.

\subsubsection{Productivity and Hydroperiod}

For both species, reaching metamorphosis requires balancing desiccation and predation risks. If a pool dries before larvae metamorphose, high larval mortality results [23,71]. If the hydroperiod is too long, larvae risk predation from an increasingly abundant and rich predator pool [65,72,73]. Inter and intra-specific competition also influence development and metamorph productivity across the hydroperiod spectrum $[23,63,74]$. In the absence of competition, both species typically achieve higher rates of metamorphosis, and salamanders attain greater metamorphic size, in pools with intermediate hydroperiods (i.e., $>14$ weeks, but non-permanent; $[71,75,76]$ ). (For wood frogs, minimal research explores how size varies with hydroperiod). Our reference-treatment metamorph-productivity results generally mirrored typical patterns observed in the absence of competition. In the cut treatments, 
by contrast, relationships between metamorph productivity and hydroperiod differed from those observed typically in the literature and in our reference treatment. Specifically, as hydroperiod increased: salamander metamorph abundance increased at a slower rate in the $30 \mathrm{~m}$ versus reference treatment; salamander metamorph SVL increased in the two cut treatments, but was unaltered in the reference treatment; and frog metamorph SVL decreased in the two cut treatments, but increased in the reference treatment. Salamander metamorph SVL also differed between the two cut treatments: SVL increased more quickly with hydroperiod in the $100 \mathrm{~m}$ versus $30 \mathrm{~m}$-buffer treatment. Cumulatively, these productivity-hydroperiod results suggest altered in-pool dynamics between predation, competition, and hydroperiod in the cut treatments.

Though metamorph productivity is tightly linked with in-pool dynamics, we were logistically constrained from collecting sufficient data to test for inter-treatment differences in in-pool conditions. Nevertheless, we suggest that the following mechanisms, both linked to in-pool dynamics, most plausibly explain inter-treatment differences in metamorph productivity and merit further investigation. First, to distinguish reference from cut-treatment patterns: use of the buffers as refuge by larval-amphibian predators and competitors. Second, to distinguish between the cut-treatments: easier predator/competitor detection of, and stronger edge effects at, pools with the narrower $30 \mathrm{~m}$ buffer. We briefly explore each of these mechanisms below.

Previous research suggests that various larval-amphibian predators and competitors would seek refuge in the buffers, in response to stressful conditions in the clearcuts (e.g., reduced water availability, restricted movement permeability, increased wind velocities; $[48,77,78])$. If this led to increased predator/competitor colonization of the embedded pools, then metamorph productivity would decline in the pools. Predation could limit metamorph abundance via direct consumption of larval amphibians and could constrain both SVL and abundance by triggering anti-predator behavior, expressed as reduced larval activity and subsequently, reduced foraging and growth rate $[55,79,80]$. Competition, by comparison, could reduce productivity by limiting resources available for growth. We expect this refuge-effect to be strongest in long-hydroperiod pools because (a) predator abundance normally increases with hydroperiod [72,73,81]; and (b) key competitors may thrive with longer hydroperiods (at least across the hydroperiods recorded in our study; e.g., midges; $[82,83]$ ).

For both species, the relationship between metamorph productivity and hydroperiod likely deviated more strongly from reference conditions in the $30 \mathrm{~m}$ versus $100 \mathrm{~m}$ treatment for two reasons. First, it may have been easier for dispersing predators and competitors to detect and colonize pools across the narrower $30 \mathrm{~m}$ buffer $[84,85]$. Second, cut-associated edge effects could extend across the buffer and into pools in the $30 \mathrm{~m}$, but not $100 \mathrm{~m}$, treatment. Edge effects, including increased light and temperature, can extend 30-60+ $\mathrm{m}$ into forest patches [86-88]. Higher in-pool light and temperature can lead to greater food availability, through enhanced periphyton [and subsequently herbivorous invertebrate] growth, and faster growth rates for amphibian larvae [89-91]. Faster larval growth rates could result in reduced mortality, leading to higher larval densities and competition. Ultimately, however, more intense competition in the $30 \mathrm{~m}$ treatment could slow growth rates and limit SVLs, with potentially negative consequences for terrestrial-stage survival $[23,92,93]$.

\section{Conclusions and Conservation Implications}

Given the negative effects that clearcuts exert on terrestrial, adult spotted salamanders and wood frogs [14,15], it is important to evaluate whether these effects are perpetuated or amplified during their aquatic life stages. In this study, we examined how buffer width affects eggmass and metamorph productivity. Overall, we found mixed effects of terrestrial habitat disturbance on these aquatic stages and species-specific responses.

The negative effects of cutting were perpetuated in the aquatic stages for spotted salamanders (i.e., declining eggmass abundance over time), but not wood frogs. Nevertheless, for both species, certain metamorph-productivity measures improved with time. This potentially indicates a degree of decoupling between terrestrial and aquatic habitats and compensation within the aquatic environment 
for disturbance in the terrestrial environment. It also suggests that the aquatic stages provide some insurance against terrestrial habitat disturbance for these species' populations. This key conclusion provides further insight into the mechanisms by which breeding-populations remained relatively resilient, despite poor adult response to terrestrial-habitat alteration [14,15]. The extent to which increased metamorph productivity subsequently enhances population fitness or individual dispersal success, thereby truly buffering populations against terrestrial habitat disturbance, merits further investigation, however. Similarly, it is important to determine whether increased metamorph productivity resulted from reduced intra-specific competition (i.e., a negative consequence of reduced eggmass abundance) or improved in-pool conditions (e.g., from edge effects and increased solar radiation in pools).

Despite the potentially beneficial decoupling of aquatic and terrestrial life-stages in terms of metamorph production over time, we emphasize that typical relationships between aquatic production and hydroperiod were disrupted for both species in both cut treatments. This disruption was especially prominent for salamanders and in the $30 \mathrm{~m}$ treatment. The insurance potential of the aquatic life stages may be weakened by the dependent relationship between reproductive output and hydroperiod, which is a changeable, landscape-specific factor.

Furthermore, the implications of decoupled metamorph production may vary with species. Spotted salamanders may be less dependent on metamorph production, being somewhat insulated from population threats by having long-lived adults capable of both temporary emigration and iteroparity [52,61]. Wood frogs may benefit more from decoupled production, since adults live just a few years and often only breed once, making population persistence more dependent on births and immigration [23,61]. Enhanced metamorph production may not always benefit wood frogs, however. If poor terrestrial habitat conditions, such as those created by cuts, inhibit metamorph growth and survival and/or instigate dispersal to other pools, then a pool might experience limited recruitment into its breeding population, despite abundant production of metamorphs. From Veysey Powell and Babbitt [14], we know that in the $30 \mathrm{~m}$ treatment, where wood frog metamorph abundance increased over time, the number of recaptured adults was persistently low. This implies that the metamorph surplus was not recruited into the breeding population, but instead died off and/or emigrated to other pools.

From a conservation perspective, the eggmass and metamorph results suggest three important objectives for these and other wetland-dependent species with complex life cycles. First, when developing conservation plans, managers must evaluate both terrestrial and aquatic responses to habitat disturbance, as responses may be either decoupled or reinforcing. Similarly, planners must assess both the effects of management actions (e.g., cutting) and how other key drivers mediate those effects. In undisturbed ephemeral pools, hydroperiod strongly structures community composition and reproductive output $[65,72,94]$. Our study demonstrates that hydroperiod remains a key driver in disturbed pool-systems, mediating the impacts of cutting on amphibian fecundity. Second, the focal species exhibited distinct responses to experimental treatments, with spotted salamanders displaying greater sensitivity, and wood frogs potentially more resilient, to cutting. Conservation planners should consider tailoring management strategies to accommodate such interspecies differences. Likewise, planners may need to customize strategies to reflect present and predicted hydroperiod regimes of individual pools. Finally, to minimize the negative effects of clearcuts on amphibian reproductive output, planners should consider retaining buffers $>30 \mathrm{~m}$ wide, especially for spotted salamanders. Though we observed detrimental cutting effects in both buffer treatments, negative effects occurred more frequently in the $30 \mathrm{~m}$ versus $100 \mathrm{~m}$ treatment.

Supplementary Materials: The following are available online at www.mdpi.com/1999-4907/8/1/10/s1, Table S1. Variance-covariance structure a of regression models; Table S2. Generalized linear mixed regression results showing the relative impact of forestry treatment, hydroperiod, and study year on eggmass and metamorph abundance and metamorph length of spotted salamanders and wood frogs. 
Acknowledgments: We acknowledge International Paper Company and Sustainable Forestry Technologies for their cooperation and permission to conduct research on their property. We thank Matt Baber, Andrew Cooper, Mark Ducey, and Jennifer Purrenhage for their research advice, our graduate students and field technicians for their dedicated service, and one anonymous reviewer for thoughtful comments. This project was supported by the: National Research Initiative of the USDA Cooperative State Research, Education, and Extension Service (grant numbers: 2003-35101-12922 and 2007-35101-18281); Northeastern States Research Cooperative; Robert and Patricia Switzer Foundation; University of New Hampshire Graduate School; University of New Hampshire Cooperative Extension; New Hampshire Agricultural Experiment Station (Scientific Contribution number: 2701); and USDA National Institute of Food and Agriculture McIntire-Stennis Project (accession number: 0226124).

Author Contributions: K.J.B. conceived and designed the experiments; K.J.B. and J.S.V.P. performed the experiments; J.S.V.P. analyzed the data; K.J.B. contributed materials and analysis tools; J.S.V.P. wrote the paper.

Conflicts of Interest: The authors declare no conflict of interest. The funding sponsors had no role in the design of the study; in the collection, analyses, or interpretation of data; in the writing of the manuscript, or in the decision to publish the results.

\section{References}

1. United Nations Forum on Forests. Conclusions and recommendations for addressing key challenges of forests and economic development. In Proceedings of the Tenth Session of the United Nations Forum on Forests, Istanbul, Turkey, 8-19 April 2013; p. 9.

2. Wondolleck, J. Public Lands Conflict and Resolution: Managing National Forest Disputes, 2nd ed.; Springer: New York, NY, USA, 1991.

3. Winkel, G. When the pendulum doesn't find its center: Environmental narratives, strategies, and forest policy change in the US Pacific Northwest. Glob. Environ. Chang. 2014, 27, 84-95. [CrossRef]

4. Ringold, P.L.; Mulder, B.; Alegria, J.; Czaplewski, R.L.; Tolle, T.; Burnett, K. Design of an ecological monitoring strategy for the Forest Plan0020in the Pacific Northwest. In Monitoring Ecosystems: Interdisciplinary Approaches for Evaluating Ecoregional Initiatives; Busch, D.E., Trexwell, J.C., Eds.; Island Press: Washington, DC, USA, 2003; pp. 73-99.

5. Tilghman, J.M.; Ramee, S.W.; Marsh, D.M. Meta-analysis of the effects of canopy removal on terrestrial salamander populations in North America. Biol. Conserv. 2012, 152, 1-9. [CrossRef]

6. Morris, D.L.A.; Porneluzi, P.; Haslerig, J.; Clawson, R.L.; Faaborg, J. Results of 20 years of experimental forest management on breeding birds in Ozark forests of Missouri, USA. For. Ecol. Manag. 2013, 310, 747-760. [CrossRef]

7. Semlitsch, R.D.; Todd, B.D.; Blomquist, S.M.; Calhoun, A.J.K.; Gibbons, J.W.; Gibbs, J.P.; Graeter, G.J.; Harper, E.B.; Hocking, D.J.; Hunter, M.L.; et al. Effects of timber harvest on amphibian populations: Understanding mechanisms from forest experiments. BioScience 2009, 59, 853-862. [CrossRef]

8. Broadmeadow, S.; Nisbet, T.R. The effects of riparian forest management on the freshwater environment: A literature review of best management practice. Hydrol. Earth Syst. Sci. 2004, 8, 286-305. [CrossRef]

9. Mayer, P.M.; Reynolds, S.K.; McCutchen, M.D.; Canfield, T.J. Meta-analysis of nitrogen removal in riparian buffers. J. Environ. Qual. 2007, 36, 1172-1180. [CrossRef] [PubMed]

10. Castelle, A.J.; Johnson, A.W.; Conolly, C. Wetland and stream buffer size requirements-A review. J. Environ. Qual. 1994, 23, 878-882. [CrossRef]

11. Dupuis, L.; Steventon, D. Riparian management and the tailed frog in northern coastal forests. For. Ecol. Manag. 1999, 124, 35-43. [CrossRef]

12. Johnston, B.; Frid, L. Clearcut logging restricts the movements of terrestrial Pacific giant salamanders (Dicamptodon tenebrosus Good). Can. J. Zool. 2002, 80, 2170-2177. [CrossRef]

13. Vesely, D.G.; McComb, W.C. Salamander abundance and amphibian species richness in riparian buffer strips in the Oregon coast range. For. Sci. 2002, 48, 291-297.

14. Veysey Powell, J.S.; Babbitt, K.J. An experimental test of buffer utility as a technique for managing pool-breeding amphibians. PLoS ONE 2015, 10, e0133642. [CrossRef] [PubMed]

15. Powell, J.S.V.; Babbitt, K.J. Despite buffers, experimental forest clearcuts impact amphibian body size and biomass. PLOS ONE 2015, 10, e0143505.

16. Semlitsch, R.D.; Bodie, J.R. Biological criteria for buffer zones around wetlands and riparian habitats for amphibians and reptiles. Conserv. Biol. 2003, 17, 1219-1228. [CrossRef] 
17. Olson, D.H.; Anderson, P.D.; Frissell, C.A.; Welsh, H.H., Jr.; Bradford, D.F. Biodiversity management approaches for stream-riparian areas: Perspectives for Pacific Northwest headwater forests, microclimates, and amphibians. For. Ecol. Manag. 2007, 246, 81-107. [CrossRef]

18. Veysey, J.S.; Babbitt, K.J.; Cooper, A. An experimental assessment of buffer width: Implications for salamander migratory behavior. Biol. Conserv. 2009, 142, 2227-2239. [CrossRef]

19. Wilbur, H.M. Propagule size, number, and dispersion pattern in Ambystoma and Asclepias. Am. Nat. 1977, 111, 43-68. [CrossRef]

20. Kinkead, K.E.; Otis, D.L. Estimating superpopulation size and annual probability of breeding for pond-breeding salamanders. Herpetologica 2007, 63, 151-162. [CrossRef]

21. Flageole, S.; Leclair, R., Jr. Etude démographique d'une population de salamandres (Ambystoma maculatum) à l'aide de la méthode squeletto-chronologique. Can. J. Zool. 1992, 70, 740-749. [CrossRef]

22. Redmer, M.; Trauth, S.E. Rana sylvatica LeConte, 1825, Wood Frog. In Amphibian Declines: The Conservation Status of United States Species; Lannoo, M.J., Ed.; University of California Press: Berkeley, CA, USA, 2005.

23. Berven, K.A. Factors affecting population fluctuations in larval and adult stages of the wood frog (Rana sylvatica). Ecology 1990, 71, 1599-1608. [CrossRef]

24. Berven, K.A. Population regulation in the wood frog, Rana sylvatica, from three diverse geographic localities. Aust. J. Ecol. 1995, 20, 385-392. [CrossRef]

25. Semlitsch, R.D. Differentiating migration and dispersal processes for pond-breeding amphibians. J. Wildl. Manag. 2008, 72, 260-267. [CrossRef]

26. Harper, E.B.; Patrick, D.A.; Gibbs, J.P. Impact of forestry practices at a landscape scale on the dynamics of amphibian populations. Ecol. Appl. 2015, 25, 2271-2284. [CrossRef] [PubMed]

27. Peterman, W.E.; Rittenhouse, T.A.G.; Earl, J.E.; Semlitsch, R.D. Demographic network and multi-season occupancy modeling of Rana sylvatica reveal spatial and temporal patterns of population connectivity and persistence. Landsc. Ecol. 2013, 28, 1601-1613. [CrossRef]

28. Regester, K.J.; Whiles, M.R.; Lips, K.R. Variation in the trophic basis of production and energy flow associated with emergence of larval salamander assemblages from forest ponds. Freshw. Biol. 2008, 53, 1754-1767. [CrossRef]

29. Regester, K.J.; Lips, K.R.; Whiles, M.R. Energy flow and subsidies associated with the complex life cycle of ambystomatid salamanders in ponds and adjacent forest in Southern Illinois. Oecologia 2006, 147, 303-314. [CrossRef] [PubMed]

30. Capps, K.A.; Berven, K.A.; Tiegs, S.D. Modelling nutrient transport and transformation by pool-breeding amphibians in forested landscapes using a 21-year dataset. Freshw. Biol. 2015, 60, 500-511. [CrossRef]

31. Pittman, S.E.; Semlitsch, R.D. Habitat type and distance to edge affect movement behavior of juvenile pond-breeding salamanders. J. Zool. 2013, 291, 154-162. [CrossRef]

32. Osbourn, M.S.; Connette, G.M.; Semlitsch, R.D. Effects of fine-scale forest habitat quality on movement and settling decisions in juvenile pond-breeding salamanders. Ecol. Appl. 2014, 24, 1719-1729. [CrossRef]

33. Wilbur, H.M. Experimental ecology of food webs: Complex systems in temporary ponds. Ecology 1997, 78, 2279-2302. [CrossRef]

34. Schriever, T.A.; Williams, D.D. Ontogenetic and individual diet variation in amphibian larvae across an environmental gradient. Freshw. Biol. 2013, 58, 223-236. [CrossRef]

35. Burley, L.A.; Moyer, A.T.; Petranka, J.W. Density of an intraguild predator mediates feeding group size, intraguild egg predation, and intra- and interspecific competition. Oecologia 2006, 148, 641-649. [CrossRef] [PubMed]

36. Relyea, R.A.; Auld, J.R. Predator- and competitor-induced plasticity: How changes in foraging morphology affect phenotypic trade-offs. Ecology 2005, 86, 1723-1729. [CrossRef]

37. Mott, C.L.; Maret, T.J. Species-specific patterns of agonistic behavior among larvae of three syntopic species of Ambystomatid salamanders. Copeia 2011, 2011, 9-17. [CrossRef]

38. Pechmann, J.H.K.; Scott, D.E.; Semlitsch, R.D.; Caldwell, J.P.; Vitt, L.J.; Gibbons, J.W. Declining amphibian populations: The problem of separating human impacts from natural fluctuations. Science 1991, 253, 892-895. [CrossRef] [PubMed]

39. Brodman, R. Intraguild predation on congeners affects size, aggression, and survival among Ambystoma Salamander larvae. J. Herpetol. 2004, 38, 21-26. [CrossRef] 
40. Rubbo, M.J.; Shea, K.; Kiesecker, J.M. The influence of multi-stage predation on population growth and the distribution of the pond-breeding salamander, Ambystoma jeffersonianum. Can. J. Zool. 2006, 84, 449-458. [CrossRef]

41. Brodman, R. Effects of intraguild interactions on fitness and microhabitat use of larval Ambystoma salamanders. Copeia 1996, 1996, 372-378. [CrossRef]

42. Davis, A.K.; Maerz, J.C. Effects of larval density on hematological stress indices in salamanders. J. Exp. Zool. 2009, 311A, 697-704. [CrossRef] [PubMed]

43. Berven, K. The genetic basis of altitudinal variation in the wood frog Rana sylvatica. I. An experimental analysis of life history traits. Evolution 1982, 36, 962-983. [CrossRef]

44. Werner, E.E.; Glennemeier, K.S. Influence of forest canopy cover on the breeding pond distributions of several amphibian species. Copeia 1999, 1999, 1-12. [CrossRef]

45. Rowe, C.L.; Dunson, W.A. Impacts of hydroperiod on growth and survival of larval amphibians in temporary ponds of central Pennsylvania, USA. Oecologia 1995, 102, 397-403. [CrossRef]

46. Semlitsch, R.D.; Walls, S.C. Competition in two species of larval salamanders-A test of geographic-variation in competitive ability. Copeia 1993, 1993, 587-595. [CrossRef]

47. Anderson, T.L.; Whiteman, H.H. Non-additive effects of intra- and interspecific competition between two larval salamanders. J. Anim. Ecol. 2015, 84, 765-772. [CrossRef] [PubMed]

48. Popescu, V.D.; Patrick, D.A.; Hunter, M.L., Jr.; Calhoun, A.J.K. The role of forest harvesting and subsequent vegetative regrowth in determining patterns of amphibian habitat use. For. Ecol. Manag. 2012, 270, 163-174. [CrossRef]

49. Pinheiro, J.C.; Bates, D.M. Mixed-Effects Models in S and S-PLUS; Springer: New York, NY, USA, 2000.

50. Crespi, E.J.; Warne, R.W. Environmental conditions experienced during the tadpole stage alter post-metamorphic glucocorticoid response to stress in an amphibian. Integr. Comp. Biol. 2013, 53, 989-1001. [CrossRef] [PubMed]

51. Homan, R.N.; Regosin, J.V.; Rodrigues, D.M.; Reed, J.M.; Windmiller, B.S.; Romero, L.M. Impacts of varying habitat quality on the physiological stress of spotted salamanders (Ambystoma maculatum). Anim. Conserv. 2003, 6, 11-18. [CrossRef]

52. Bull, J.J.; Shine, R. Iteroparous animals that skip opportunities for reproduction. Am. Nat. 1979, 114, $296-303$. [CrossRef]

53. Spotila, J.R. Role of temperature and water in the ecology of lungless salamanders. Ecol. Monogr. 1972, 42, 95-125. [CrossRef]

54. Crouch, W.B.; Paton, P.W.C. Using egg-mass counts to monitor wood frog populations. Wildl. Soc. Bull. 2000, 28, 895-901.

55. Savage, W.K.; Zamudio, K.R. Ambystoma maculatum (Shaw, 1802), Spotted Salamander. In Amphibian Declines: The Conservation Status of United States Species; Lannoo, M.J., Ed.; University of California Press: Berkeley, CA, USA, 2005; pp. 621-627.

56. Veysey, J.S.; Mattfeldt, S.D.; Babbitt, K.J. Comparative influence of isolation, landscape, and wetland characteristics on egg-mass abundance of two pool-breeding amphibian species. Landsc. Ecol. 2011, 26, 661-672. [CrossRef]

57. Scott, D.E. Effects of larval density in Ambystoma opacum: An experiment in large-scale field enclosures. Ecology 1990, 71, 296-306. [CrossRef]

58. Taylor, B.E.; Scott, D.E.; Gibbons, J.W. Catastrophic reproductive failure, terrestrial survival, and persistence of the marbled salamander. Conserv. Biol. 2006, 20, 792-801. [CrossRef] [PubMed]

59. Berven, K.A.; Grudzien, T.A. Dispersal in the wood frog (Rana sylvatica): Implications for genetic population-structure. Evolution 1990, 44, 2047-2056. [CrossRef]

60. Gamble, L.R.; McGarigal, K.; Compton, B.W. Fidelity and dispersal in the pond-breeding amphibian, Ambystoma opacum: Implications for spatio-temporal population dynamics and conservation. Biol. Conserv. 2007, 139, 247-257. [CrossRef]

61. Harper, E.B.; Rittenhouse, T.A.G.; Semlitsch, R.D. Demographic consequences of terrestrial habitat loss for pool-breeding amphibians: Predicting extinction risks associated with inadequate size of buffer zones. Conserv. Biol. 2008, 22, 1205-1215. [CrossRef] [PubMed]

62. Berven, K.A. Density dependence in the terrestrial stage of wood frogs: Evidence from a 21-year population study. Copeia 2009, 2009, 328-338. [CrossRef] 
63. Wilbur, H.M. Competition, predation, and structure of Ambystoma-Rana-sylvatica community. Ecology 1972, 53, 3-21. [CrossRef]

64. Bennett, A.M.; Murray, D.L. Maternal body condition influences magnitude of anti-predator response in offspring. Proc. R. Soc. B Biol. Sci. 2014, 281, 20141806. [CrossRef] [PubMed]

65. Wellborn, G.A.; Skelly, D.K.; Werner, E.E. Mechanisms creating community structure across a freshwater habitat gradient. Annu. Rev. Ecol. Evolut. Syst. 1996, 27, 337-563. [CrossRef]

66. Scott, D.E.; Fore, M.R. The effect of food limitation on lipid levels, growth, and reproduction in the marbled salamander, Ambystoma opacum. Herpetologica 1995, 51, 462-471.

67. Berven, K.A. Factors affecting variation in reproductive traits within a population of wood frogs (Rana sylvatica). Copeia 1988, 1988, 605-615. [CrossRef]

68. Woodward, B.D. Local intraspecific variation in clutch parameters in the spotted salamander (Ambystoma maculatum). Copeia 1982, 1982, 157-160. [CrossRef]

69. Smith-Gill, S.J.; Berven, K.A. In vitro fertilization and assessment of male reproductive potential using mammalian gonadotropin-releasing hormone to induce spermiation in Rana sylvatica. Copeia 1980, 1980, 723-728. [CrossRef]

70. Chandler, C.H.; Zamudio, K.R. Reproductive success by large, closely related males facilitated by sperm storage in an aggregate breeding amphibian. Mol. Ecol. 2008, 17, 1564-1576. [CrossRef] [PubMed]

71. Shoop, C.R. Yearly variation in larval survival of Ambystoma maculatum. Ecology 1974, 55, 440-444. [CrossRef]

72. Batzer, D.P.; Wissinger, S.A. Ecology of insect communities in nontidal wetlands. Annu. Rev. Entomol. 1996, 41, 75-100. [CrossRef] [PubMed]

73. Tarr, T.; Baber, M.; Babbitt, K. Macroinvertebrate community structure across a wetland hydroperiod gradient in southern New Hampshire, USA. Wetl. Ecol. Manag. 2005, 13, 321-334. [CrossRef]

74. Holbrook, C.T.; Petranka, J.W. Ecological interactions between Rana sylvatica and Ambystoma maculatum: Evidence of interspecific competition and facultative intraguild predation. Copeia 2004, 2004, 932-939. [CrossRef]

75. Karraker, N.E.; Gibbs, J.P. Amphibian production in forested landscapes in relation to wetland hydroperiod: A case study of vernal pools and beaver ponds. Biol. Conserv. 2009, 142, 2293-2302. [CrossRef]

76. Phillips, C.A.; Johnson, J.R.; Dreslik, M.J.; Petzing, J.E. Effects of hydroperiod on recruitment of mole salamanders (genus Ambystoma) at a temporary pond in Vermilion County, Illinois. Trans. Ill. State Acad. Sci. 2002, 95, 131-139.

77. Semlitsch, R.D.; Conner, C.A.; Hocking, D.J.; Rittenhouse, T.A.G.; Harper, E.B. Effects of timber harvesting on pond-breeding amphibian persistence: Testing the evacuation hypothesis. Ecol. Appl. 2009, 18, $283-289$. [CrossRef]

78. Whitaker, D.M.; Carroll, A.L.; Montevecchi, W.A. Elevated numbers of flying insects and insectivorous birds in riparian buffer strips. Can. J. Zool. 2000, 78, 740-747. [CrossRef]

79. Relyea, R.A. Morphological and behavioral plasticity of larval anurans in response to different predators. Ecology 2001, 82, 523-540. [CrossRef]

80. Schoeppner, N.M.; Relyea, R.A. Phenotypic plasticity in response to fine-grained environmental variation in predation. Funct. Ecol. 2009, 23, 587-594. [CrossRef]

81. Babbitt, K.J.; Baber, M.J.; Tarr, T.L. Patterns of larval amphibian distribution along a wetland hydroperiod gradient. Can. J. Zool. 2003, 81, 1539-1552. [CrossRef]

82. Brooks, R.T. Annual and seasonal variation and the effects of hydroperiod on benthic macroinvertebrates of seasonal forest ("vernal") ponds in central Massachusetts, USA. Wetlands 2000, 20, 707-715. [CrossRef]

83. Hanson, M.A.; Church, J.O.; Miller, A.T.; Palik, B.J.; Butler, M.G. Testing the efficacy of harvest buffers on the invertebrate communities in seasonal forest wetlands. In Summaries of Wildlife Research Findings; Wingate, P.J., Kimmel, R.O., Lawrence, J.S., Lenarz, M.S., Eds.; Minnesota Department of Natural Resources, Division of Fish and Wildlife, Wildlife Populations and Research Unit: St. Paul, MN, USA, 2005; pp. 164-179.

84. Miller, A.T. Aquatic Communities in Northern Forest Wetlands: Characteristics and Influences of Timber Harvest. Master's Thesis, North Dakota State University of Agriculture and Applied Science, Fargo, ND, USA, 2001.

85. Hanson, M.; Palik, B.; Church, J.; Miller, A. Influences of upland timber harvest on aquatic invertebrate communities in seasonal ponds: Efficacy of forested buffers. Wetl. Ecol. Manag. 2010, 18, 255-267. [CrossRef] 
86. Chen, J.; Saunders, S.C.; Crow, T.R.; Naiman, R.J.; Brosofske, K.D.; Mroz, G.D.; Brookshire, B.L.; Franklin, J.F. Microclimate in forest ecosystem and landscape ecology. BioScience 1999, 49, 288-297. [CrossRef]

87. De Maynadier, P.G.; Hunter, M.L. Effects of silvicultural edges on the distribution and abundance of amphibians in Maine. Conserv. Biol. 1998, 12, 340-352. [CrossRef]

88. Hocking, D.J.; Babbitt, K.J.; Yamasaki, M. Comparison of silvicultural and natural disturbance effects on terrestrial salamanders in northern hardwood forests. Biol. Conserv. 2013, 167, 194-202. [CrossRef]

89. Halverson, M.A.; Skelly, D.K.; Kiesecker, J.M.; Freidenburg, L.K. Forest mediated light regime linked to amphibian distribution and performance. Oecologia 2003, 134, 360-364. [CrossRef] [PubMed]

90. Skelly, D.K.; Freidenburg, L.K.; Kiesecker, J.M. Forest canopy and the performance of larval amphibians. Ecology 2002, 83, 983-992. [CrossRef]

91. Batzer, D.P.; George, B.M.; Braccia, A. Aquatic invertebrate responses to timber harvest in a bottomland hardwood wetland of South Carolina. For. Sci. 2005, 51, 284-291.

92. Altwegg, R.; Reyer, H.-U. Patterns of natural selection on size at metamorphosis in water frogs. Evolution 2003, 57, 872-882. [CrossRef] [PubMed]

93. Scott, D.E. The effect of larval density on adult demographic traits in Ambystoma opacum. Ecology 1994, 75, 1383-1396. [CrossRef]

94. Herrmann, H.L.; Babbitt, K.J.; Baber, M.J.; Congalton, R.G. Effects of landscape characteristics on amphibian distribution in a forest-dominated landscape. Biol. Conserv. 2005, 123, 139-149. [CrossRef]

(C) 2016 by the authors; licensee MDPI, Basel, Switzerland. This article is an open access article distributed under the terms and conditions of the Creative Commons Attribution (CC-BY) license (http://creativecommons.org/licenses/by/4.0/). 